\title{
Mikroorganismoek minbizia eragin dezakete?
}

\author{
(Can microorganisms induce cancer?)
}

\author{
Aitana Arbizu, Aitziber Antoran, Idoia Buldain, Aize Pellon, \\ Xabier Guruceaga, Leire Martin-Souto, Leire Aparicio, Aitor Rementeria, \\ Fernando L. Hernando, Andoni Ramirez-Garcia
}

Onddo eta Bakterioen Biomika ikerketa taldea. Immunologia, Mikrobiologia eta Parasitologia saila, Zientzia eta Teknologia Fakultatea. Euskal Herriko Unibertsitatea (UPV/EHU)

andoni.ramirez@ehu.eus

DOI: $10.1387 /$ ekaia.19667

Laburpena: Ikerketa askok mikroorganismoen eta minbizien arteko erlazioak aztertu dituzte, eta erakutsi dute mikroorganismo batzuek minbiziaren agerpena saihesten dutela eta beste batzuek, aldiz, minbizia eragin dezaketela. Hain zuzen ere, gero eta artikulu zientifiko gehiago argitaratzen ari dira mikroorganismoak minbiziaren sortzearekin, ezarpenarekin eta sakabanaketarekin erlazionatuz. Izan ere, mikroorganismoek minbizi guztien \% 17,8 eragiten dutela estimatu da. Minbizia sortzeko birusen gaitasuna da gehien ikertu dena eta, ondorioz, minbizia sor dezaketen mekanismo desberdin asko deskribatu dira. Minbizia Ikertzeko Nazioarteko Agentziak zortzi birus 1. mailako «gizakiontzat kartzinogeno»-tzat sailkatu ditu; haien artean, giza papiloma birusa, bi herpesbirus eta bi hepatitisaren birus aurkitzen dira. Bakterioei dagokienez, minbizi-eragileen artean, Helicobacter pylori da gehien ikertu dena urdaileko minbiziarekin erlazionatuta. Baina honetaz gain, beste hainbat bakterio, hala nola Salmonella typhi, Chlamydia pneumoniae eta Streptococcus bovis minbiziarekin zuzenki erlazionatu dira. Onddoek daukaten minbiziarekiko erlazioa oso gutxi ikertu den arren, mikroorganismo hauek sortutako toxina batzuek minbizia eragin dezaketela frogatu da. Horrez gain, Candida albicans onddoak minbiziaren sorrera eta hedapena eragin dezakeen hainbat mekanismo deskribatu dira. Orain arte egindako ikerketek mikroorganismoek minbiziaren garapenean eta sustapenean daukaten eragina agerrarazi dute. Hori dela eta, etorkizunean minbiziari aurre egiteko, minbiziaren eta mikroorganismoen arteko erlazioan sakontzea ezinbestekoa da.

Hitz gakoak: mikrobio, metastasi, minbizia, infekzioa, birus, bakterio, onddo. 


\begin{abstract}
Many studies have analyzed relationships between microorganisms and cancer, demonstrating that microorganisms are able to prevent the onset of cancer and, others to provoke it. Specifically, more and more scientific articles are publishing on microorganisms, linking them to the creation, implementation and dispersion of cancer. In fact, it is estimated that microorganisms cause $17.8 \%$ of all cancers. The cancercausing viral capability is the most studied and, in consequence, many different viral mechanisms that can cause cancer have been described. The International Cancer Research Institute has categorized eight viruses for the first time as «carcinogenic to humans», including a human papillomavirus, two herpesvirus and two hepatitis viruses. Regarding bacteria, among cancerous agents, Helicobacter pylori is the most studied in relation to stomach cancer. In addition, many other bacteria, such as Salmonella typhi, Chlamydia pneumoniae and Streptococcus bovis, have been directly related to cancer. Although relatively little research on the effect of fungi on cancer has been investigated, some of the toxins produced by these microorganisms have been shown to cause cancer. In addition, some mechanism for the generation and spread of cancer have been described in Candida albicans. Studies to date have shown the influence of microorganisms on the development and promotion of cancer. For this reason, to face cancer in the next future, deepen into the relationship between cancer and microorganisms will be essential.
\end{abstract}

Keywords: microbe, metastasis, cancer, infection, virus, bacterium, fungus.

\title{
1. MIKROORGANISMOAK ETA MINBIZIAREN AGERPENA
}

Geure garaian, gizaki askok bizitzan zehar aurre egin beharko dioten arazo larrienetariko bat minbizia da. Gaixotasun horren tratamendua oso zaila da, minbizi mota desberdin asko baitira, bakoitzak berezko ezaugarriak dituela. Hala ere, kasu gehienetan gaitz hau aurrera doan heinean, zelulen kontrolik gabeko ugalketa, ehunen inbasioa eta, kasu txarrenetan, metastasia gerta daitezke. Eritasun honen garapenean tumore primario batetik zelula gaizto batzuk askatu eta, odol-hodi barneko migrazioaren bidez, beste organo batera heltzen dira. Han, zelulak atxiki, finkatu eta ugalduko dira jatorrizko tumorean egiten zuten bezala, eta tumore sekundarioa sortuko dute.

Gaur egun gertatzen ari den bioteknologiako eta biomedikuntzako iraultzari esker, gaixotasun honen detekzioan, kontrolean eta sendatzean aurrerapauso oso handiak ematen ari dira. Hala ere, aurrerabide horiek minbizi motaren eta eboluzio-mailaren araberakoak dira eta, oraingoz, gaitz beldurgarri honek heriotzarekin eta sufrimenduarekin lotuta jarraitzen du.

Zenbait ikerketatan, ondorioztatu da mikroorganismo batzuek, batez ere gure mikrobiotarekin eta elikagai probiotikoekin erlazionatutakoek, minbiziaren agerpena prebenitzeko gaitasuna omen dutela. Minbiziaren 
Mikroorganismoek minbizia eragin dezakete?

aurkako mikroorganismoen efektu positiboak oso gai interesgarria izan arren, artikulu honen helburua mikroorganismoek minbiziaren sorreran eta garapenean izan dezaketen eragina azaltzea da.

Mikroorganismoen eta minbiziaren arteko erlazioa ez da berria; aspalditik dakigu immunoeskasia daukaten pertsonek infekzioak izateko arrisku handiagoa daukatela. Horixe da, hain zuzen ere, pazienteei gerta dakiekeena minbiziaren eta tratamendu kimioterapeutikoen eraginez. Gure immunitate-sistema normalean gorputzeko mikrobiotarekiko oreka mantentzeko eta mikrobio-inbasioak ekiditeko prestatuta dago, baina immunitate-sistema kaltetzean edota erantzun immunea ahultzean, behintzat denboraldi batez, gaixotasun infekziosoak jasateko arriskua esponentzialki emendatzen da. Hori gertatzen da mikroorganismoak, gure gorputzean bizi direnak barne, egoera horretaz balia daitezkeelako gaixotasun infekziosoa garatzeko.

Hau guztia kontuan hartuta, azken hamarkadetan alderantzizko prozesua ere posiblea dela frogatu da, hots, mikroorganismoek mekanismo desberdin askoren bidez minbizia eragin dezaketela (1. Irudia). Kontu hau berriagoa, harrigarriagoa eta zientifikoki erakargarriagoa da. Izan ere, gero eta artikulu zientifiko gehiago argitaratzen ari dira mikroorganismoak minbiziaren sortzearekin, ezartzearekin eta sakabanatzearekin erlazionatuz. Are gehiago, mikroorganismo talde guztiek, mikrobiotaren parte direnak barne, minbiziaren prozesuan parte har dezakete eta minbizi guztien $\% 17,8$ eragiten dutela estimatu zen $[1,2]$. Hau dela eta, hurrengo paragrafoetan birus, bakterioek eta onddoek erabilitako mekanismo garrantzitsuenak azalduko ditugu.

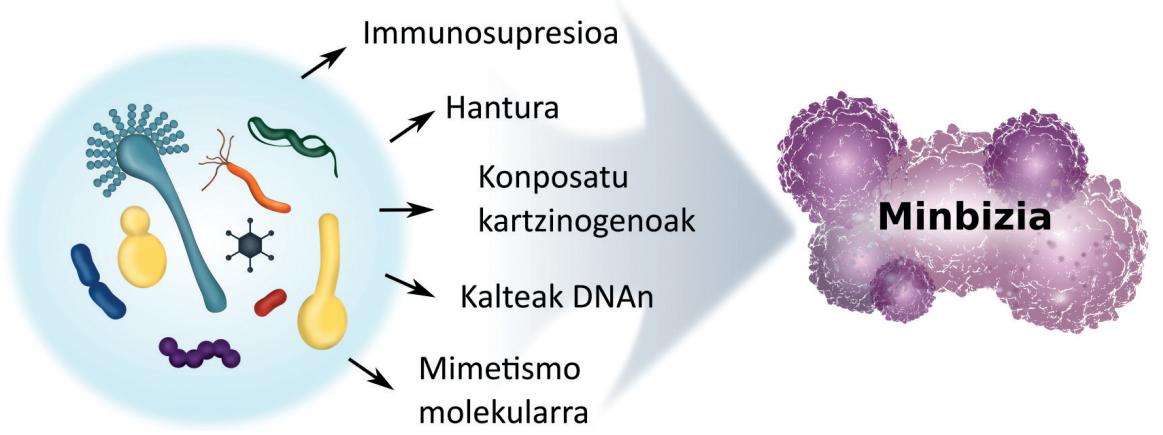

1. irudia. Mikroorganismoek minbizia sortzeko erabil ditzaketen mekanismoak. 
A. Arbizu, A. Antoran, I. Buldain, A. Pellon, X. Guruceaga, L. Martin-Souto, L. Aparicio, A. Rementeria, F.L. Hernando, A. Ramirez-Garcia

\section{BIRUSAK}

Mikroorganismo guztien artean birusak ondo aztertutako minbizi eratzaileak dira. Orokorrean, datu kontserbadoreak kontuan hartuz, minbizi guztietatik \% 12 birusek eragin omen dituzte, eta proportzioa handiagoa da garapen-bidean dauden herrialdeak besterik ez baditugu kontuan hartzen [1]. Hala ere, beste mikroorganismoekin gertatzen den bezala, birusek egindako infekzio batzuk minbizia sortzeko beharrezkoak izan arren, berez ez dira nahikoak [3]. Izan ere, infekzio biriko bat hasten denetik tumoregenesirainoko bidea geldoa da (urteak edo hamarkadak) eta oso kasu gutxitan amaitzen da minbizian [4].

Gaur egun, Minbizia Ikertzeko Nazioarteko Agentziak (International Agency for Research on Cancer (IARC) (https://www.iarc.fr/)) hurrengo birusak «gizakiontzat kartzinogenoak» (carcinogenic to humans, Group 1) diren konposatuen lehenengo taldean sailkatu ditu: Linfotropikoak diren bi herpesbirus: Epstein Barr birusa (EBV/HHV4) eta giza Kaposi sarkomarekin erlazionaturiko herpesbirusa (KSHV/HHV8); bi hepatitis birus: $\mathrm{B}$ eta $\mathrm{C}$ birusak (HBV eta $\mathrm{HCV}$ ); $\mathrm{T}$ zelulen 1-motako birus linfotropikoa (HTLV-1); giza papilomaren birusa (HPV); Merkel zeluletako poliomabirusa (MCV) eta 1-motako giza immunoeskasiaren birusa (HIV-1)[1]. Birus hauetako batzuek, EBV, HPV, HTLV-1 eta KSHV esaterako, eragin zuzena dute kartzinogenesian; beste batzuek (HBV eta HCV birusek, adibidez), aldiz, eragin ez-zuzena daukate, batez ere infekzioa kronifikatzearen ondorioz. HIV-1en kasuan HIESaren ondorioz agertzen den immunosupresioaren bitartez minbizia izateko probabilitatea emendatzen da.

Beraz, birus onkogenikoek minbizia sortzeko erabil ditzaketen mekanismoak bi mailatan bana daitezke: zuzenak eta ez-zuzenak. Alde batetik, modu zuzenean onkogeneak aktibatu edo gene tumore-ezabatzaileak inhibitu ditzakete. Gene hauen adierazpenean aldaketak eragitean minbizia garatu daiteke, zelulen ugalketa estimulatu eta zelulen apoptosia (heriotza) ekidin daitekeelako (2. Irudia). Jakina denez, giza tumoregenikoak diren birusek, HCV izan ezik, gutxienez onkogene bat kodetzen dute, eta minbiziaren biogenesian paper garrantzitsua jokatzen dute [5].

Bestalde, infekzio kronikoen eraginez, era ez-zuzenean minbizia faboratu dezaketen estres oxidatzailea eta hantura induzitzeko ahalmena dute. Birus onkogeniko batzuk hantura-prozesuekin estuki erlazionatuta daude. Adibidez, kartzinoma hepatozelularra eragin dezaketen HBV eta EBV birusek tumore-mikroingurunea modulatu dezakete zitokina askoren adierazpena induzituz [6-9]. Hantura infekzio birikoen aurkako erantzun garrantzitsua da, baina gehiegizko hanturak zelula ostalarian efektu mutagenikoa izan dezake. Hantura kronikoak tumoregenesiaz aparte, zelulen proliferazioan, biziraupenean, inbasioan, angiogenesian eta metastasian parte har- 
tzen du [10]. Izan ere, zitokinak eta hazkuntza-faktoreak minbizia sortzeko behar diren aldaketa genetiko eta epigenetikoak eragin ahal izateko beharrezkoak dira askotan [3] (2. Irudia).

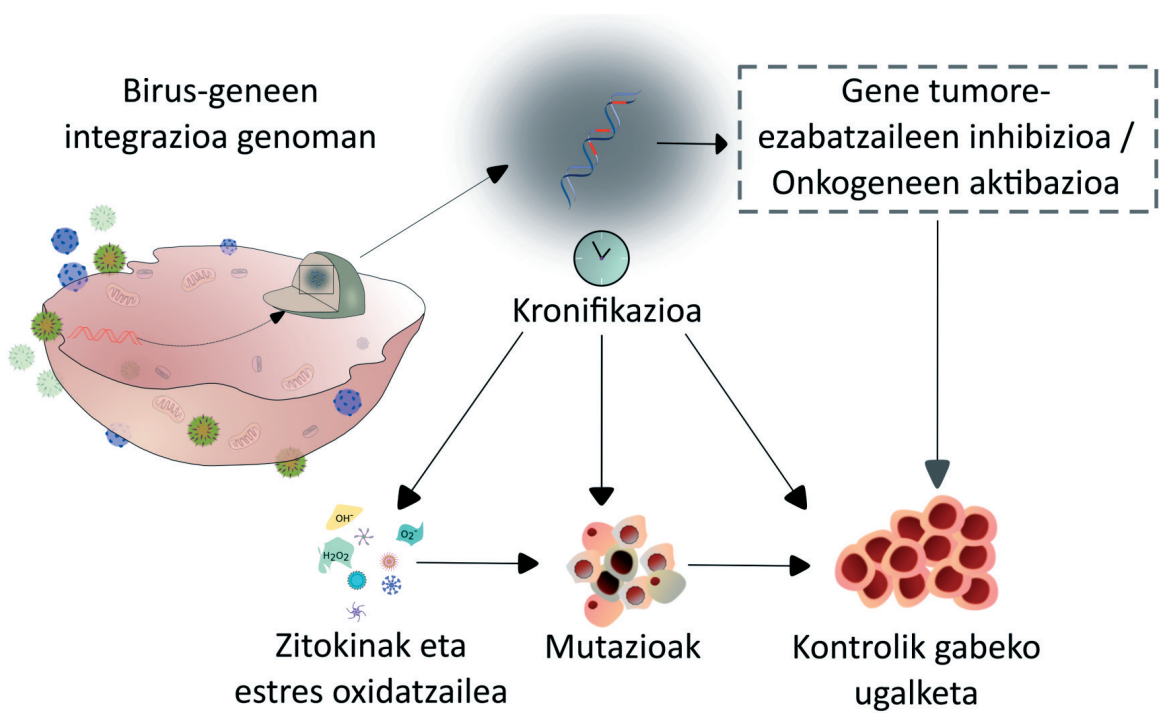

2. irudia. Birus onkogenikoek minbizia sortzeko erabil ditzaketen mekanismoak.

Alde batetik giza genoman integratzen direnean onkogeneak aktibatu edo gene tumore-ezabatzaileak inhibitu ditzakete era zuzenean. Beste alde batetik, infekzioa kronifikatzen bada, minbizia faboratu dezaketeen estres oxidatzailea eta hantura induzitzeko ahalmena dute. Horiek efektu mutagenikoa izan dezakete, eta zelulen ugalketan, biziraupenean, inbasioan, angiogenesian eta metastasian parte har dezakete.

Hurrengo paragrafoetan, giza minbiziarekin erlazionaturiko birus onkogeniko garrantzitsuenak (MCV, papilomabirusa, HBV, HCV, KSHV, EBV eta HTLV-1) eta haien mekanismoen deskribapen laburra egingo dugu.

MCV kate bikoitzeko DNA zirkularra eta kapside ikosaedrikoa duten Polyomaviridae familiako birus txikiak eta biluziak dira. Birus hauek indibiduo osasuntsuen \% 25-64an detekta daitezke [11], baina indibiduo immunogutxituengan eragina izaten dute, Merkel zelulen kartzinoma izeneko larruazaleko minbizia gauzatuz. Birus hauek bere DNA ostalariaren genoman txertatzen dute, eta birusak kodetutako T-antigeno izeneko onkoproteinak ekoitzarazten dizkiote ostalariaren genoman eraldaketak sortuz, hala nola, hipermetilazioak eta mutazioak. Minbiziarekin erlazionatuta omen dauden Polyomaviridae familiako beste birus garrantzitsu batzuk JC (John 
A. Arbizu, A. Antoran, I. Buldain, A. Pellon, X. Guruceaga, L. Martin-Souto, L. Aparicio, A. Rementeria, F.L. Hernando, A. Ramirez-Garcia

Cunningham) eta BK birusak dira, $\% 75$ eta $\%$ 100eko seroprebalentzia dutenak, hurrenez hurren $[5,12]$. IARCek 2B taldean kartzinogeno posibletzat sailkatu berri ditu. JC birusaren kasuan, haren proteina biriko nagusia large tumor antigen (T-Ag) da. Proteina hau hainbat zelula-faktoretara, erretinoblastoma (pRb) eta p53 proteinetara, besteak beste, lotzeko gai da, ziklo zelularraren erregulazioa eraldatuz [12].

Minbiziarekin erlazionaturiko beste birus batzuk papilomabirusak dira. Papilomaviridae familiako birus txiki eta biluzi hauek kate bikoitzeko DNA daukate. Papilomabirusen artean, hainbat genotipo desberdin daude [13]. Arrisku handiko genotipoak, uzki eta genitaletako minbiziarekin, larruazalekoarekin edota buru eta lepoko minbiziarekin erlazionaturik daude [14]. Hain zuzen ere, 16 eta 18. genotipoak umetoki-lepoko minbizien eta minbizi uzki-genitalen \% 50-20ren eragileak dira, hurrenez hurren [15]. Arrisku handiko genotipoek minbizia gauzatu dezakete zelula epitelialetan, besteak beste, E6 eta E7 onkoproteinak ekoiztuz. Onkoproteina hauek p53 eta pRb gene tumore-ezabatzaileekin lotzen dira, hurrenez hurren, zelularen proliferazioa eraginez. Gainera, 16-HPV genotipoak ekoizten dituen E5, E6 eta E7 onkoproteinek ziklooxigenasa (COX) entzimaren ekoizpena gauzatzen dute, horren ondorioz hanturarekin erlazionaturik dauden prostaglandinak ekoiztuz. Horrez gain, birus honek kutsatutako zeluletan TNF- $\alpha$ eta IL-6 zitokinen seinalizazioa oztopatzen da, haien hazkuntza potentziala emendatuz. Hala eta guztiz ere, minbizia garatu ahal izateko, beharrezkoak dira mutazio osagarriak [15].

Hepatitisa eragiten duten bi birus oso desberdin ere, HBV eta $\mathrm{HCV}$, minbiziarekin erlazionatu dira, hepatokartzinomarekin (HCC) hain zuzen ere. Mundu mailan, HBVk eta HCVek kutsatutako 350 eta 270 milioi pertsona daude, hurrenez hurren [14]. Normalean infekzio biriko hau pairatzen denean hepatitisa garatzen da, baina hau ondo sendatzen ez bada, luzaturiko hantura baten ondorioz zirrosia eta $\mathrm{HCCa}$ ager daitezke. Birus hauen mekanismo orokorra onkogenesiarekin erlazionatutako gene batzuetan, hala nola, telomeroen mantenuan, zelularen zikloan, eta estres oxidatiboan mutazioak eragitea da [16]. HCCa oso minbizi mota heterogeneoa da eta mutazio askoren pilaketaren ondorioz agertzen da. HBV, konkretuki, kate bikoitzeko DNA birusa da eta HBx onkoproteina ekoizten du. Proteina honek ostalariaren eta birusaren gene ugari aktibatuz transdukzio seinaleak, zelularen proliferazioa, apoptosia eta inbasioa modulatzen ditu [5]. HCV, ordea, polaritate positiboko kate bakarreko RNA birusa da. Kasu honetan alderantzizko transkriptasa (RNA erabiliz DNA ekoizten duen entzima da, RNA erretrobirusek behar dutena zelularen DNAan txertatu ahal izateko) ez duenez, ezin da ostalariaren genoman txertatu, ez eta onkoproteinarik ekoiztu ere [15]. Haren mekanismoa metilazioan oinarritzen da, ziklo zelularraren erregulazioan eta apoptosian erlazionaturiko gene espezifikoen hipermetilazioa eragiten du [16]. 
Mikroorganismoek minbizia eragin dezakete?

Minbiziaren sorreran eragina daukaten beste birus batzuk Herpesviridae familiako KSHV (herpesbirus-8) eta EBV (herpesbirus-4) gamma herpesbirusak dira. Biak kate bikoitzeko DNA birusak dira eta ostalariaren genoman txertatzen dira $[13,15]$. Hain zuzen ere, KSHV ugariagoa da garapen bidean dauden herrialdeetan: Afrikan, esaterako, haur minbiziaren sortzaile nagusia da [14]. KSHVk egindako infekzioaren ondorioz, proteina transformatzaileak eta faktore anti-apoptotikoak ekoizten dira. Bere izenak dionez, birus honek pertsona immunogutxituen larruazalean, biriketan eta liseri-hodian batez ere, Kaposi Sarkoma (minbizi mota bat) eragin dezake [15]. Beste alde batetik, EBV oso heterogeneoa da eta ostalariarekin lehenengo kontaktuaren ostean ostalariarengan mantenduko da bizitza osoan zehar latentzian [17]. Izan ere, populazio helduaren \% 90 baino gehiago birus honen eramailea da $[18,19]$. Birusak zelulak infektatzen dituenean, batez ere B linfozitoak, DNAren erreplikazioa eta konponketa, nukleotidoen biosintesia eta ziklo zelularra trabatzen duten proteinak ekoizten dira. Horrela, birus hau gaixotasun askorekin lotuta dago, besteak beste Burkitt linfomarekin, Hodgkin gaixotasunarekin, ez-Hodgkin linfomarekin, eta kartzinoma nasofaringeoarekin [13].

Birusak aztertzen amaitzeko, $\mathrm{T}$ zelulen leuzemiarekin erlazionatu den HTLV-1 polaritate positiboko RNA erretrobirusa aipatu behar da [13]. Mundu mailan, birus honek 12-25 milioi pertsona infektatzen ditu, eta kasuen \% 5ean gaixotasuna garatzen du [13]. Kasu honetan, ostalariaren $\mathrm{CD}^{+} \mathrm{T}$ zelulen genoman txertatzen da bere alderantzizko transkriptasari esker. Ondoren, zelularen hazkuntzan eta zatiketan eragina duen Tax onkoproteina ekoiztu ahal du [15]. Horren ondorioz, minbizia agertzeko posibilitatea handiagotzen da.

\section{BAKTERIOAK}

Azken urteotan, ikerketa batzuek azpimarratu dute bakterioen azterketa lagungarria izan daitekeela minbiziaren diagnostikoan, prebentzioan eta tratamenduan. Beste ikerketa batzuek, aldiz, bakterioak kartzinogenesiarekin zuzenki erlazionatu dituzte. Kasu horretan, minbizia eragiten duten bakterioen mekanismo nagusiak infekzioaren kronifikazioa eta ondoriozko hantura kronikoa, birusekin azaldu den bezala, eta erantzun immunea ekiditea dira. Honekin batera, zenbait bakteriok zelulen zikloa aldarazten duten toxinak ekoitz ditzakete linfozitoen erreplikazio klonala ekidinez ala zelulen proliferazioa sustatuz [20,21].

Batez ere, bakterio eta minbiziaren arteko erlazioa Helicobacter pylori eta urdaileko minbiziaren kasuan sakonki aztertu da. Baina honetaz gain, beste hainbat bakterio, hala nola Salmonella typhi, Chlamydia pneumoniae eta Streptococcus bovis, minbiziarekin zuzenki erlazionatu dira [20]. Ho- 
A. Arbizu, A. Antoran, I. Buldain, A. Pellon, X. Guruceaga, L. Martin-Souto, L. Aparicio, A. Rementeria, F.L. Hernando, A. Ramirez-Garcia

rregatik, azken bakterio hauei buruzko deskribapen laburra egingo dugu, hurrengo puntuan $H$. pyloriren adibidea luzeago azaltzeko.

Aipatutako bakterioen artean, $S$. typhi behazun-xixkuko minbiziarekin erlazionatu da. Munduan minbizi mota honek urteko 17 millioiko intzidentzia dauka eta, gainera, pronostiko txarrarekin erlazionatuta dago. Kasu honetan $S$. typhi bakterioaren infekzio kronikoa pairatzeak minbizi hau garatzeko arriskua 8,5 aldiz handitzen du, arrisku faktore garrantzitsuenetarikoa izanik [20].

Biriketako minbiziarekin mikroorganismoek izan dezaketen erlazioa ere nabarmendu behar da gaixotasunak \% 60ko heriotza-tasa daukalako detekzio ondorengo lehenengo urtean [20]. Zenbait ikerketak C. pneumoniae arnasbideetako patogeno arruntak biriketan eragindako hantura kronikoak minbizi hau pairatzeko arriskua handitzen duela adierazi dute [22]. Gainera, biriketako minbizia pairatzen duten pazienteengan bakterio honen aurkako antigorputz titulu altuak eta iraunkorrak detektatu dira [20]. Aldi berean, $C$. pneumoniaeren aurkako IgA antigorputz titulu handiak edukitzea biriketako minbizia pairatzeko arriskua \% 50-100 tartean handitzearekin erlazionatu da [23].

Bestalde, garatutako herrialdeetan koloneko minbizia minbizirik ohikoenetarikoa da, eta haren intzidentzia adinarekin asko handitzen da (SEER Cancer Statistics Review, 1975-2014). Hainbat bakterio kolonaren infekzio kronikoarekin eta minbizia garatzeko arrisku handiagoarekin erlazionatu dira [24], hala nola Fusobacterium spp. [25, 26], Escherichia coli [27] eta Streptoccocus spp. [28, 29]. Bakterio horiek erabilitako mekanismoak oso ezagunak izan ez arren, Streptococcus bovis bakterioaren kasuan bere paretako proteinak koloneko minbiziaren garapena azkartzeko gai direla frogatuta dago [30].

Lehen aipatu dugunez, minbizi-bakterio eragileen artean, H. pylori da gehien aztertu dena. Bakterio gram-negatibo honek gizakien urdaila kolonizatzeko ahalmena dauka eta bakterioak ekoizturiko ureasek horren latza den ingurune azidoan bizitzea baimentzen diote, urea amoniako bilakatuz eta horrela ingurune neutroa lortuz [31]. Bakterio honen presentzia gizakion urdailean oso ohikoa da; izan ere, munduko populazioaren erdia $H$. pylorik urdailean infektatuta omen dago. Kasu gehienetan, sintomarik gabeko hantura kronikoa sortzen du, baina infektaturiko populazioaren $\%$ 10ek ultzera peptidikoa, \% 1-3k urdaileko adenokartzinoma eta \% 0,1ek mukosetako ehun linfoidearen linfoma garatuko du [31].

Munduko Osasun Erakundeak I. taldeko giza kartzinogenotzat sailkaturiko lehenengo bakterioa da (IARC Working group, 1994). Hortik aurrera, kasu kliniko askok $H$. pyloriren eta giza minbiziaren arteko erlazio kausala indartu dute [14, 32-34]. Hain zuzen ere, $H$. pylorik urtero munduan 780.000 urdaileko minbizi eragiten dituela estimatzen da, munduko minbizi guztien \% 6,2 [35]. Gainera, azpimarratzekoa da urdaileko minbiziaren 
heriotza-tasa altua, minbizi heriotzen artean hirugarren kausa [36, 37]. Urdaileko minbiziaren garapena prozesu multifaktoriala izan arren, zeinetan ostalariaren sentikortasuna eta ingurune faktoreek eragina daukaten, hurrengo paragrafoetan $H$. pylorik izan ditzakeen mekanismo protumoralak azalduko ditugu, 3. irudian ikus daitezkeenak.

a)

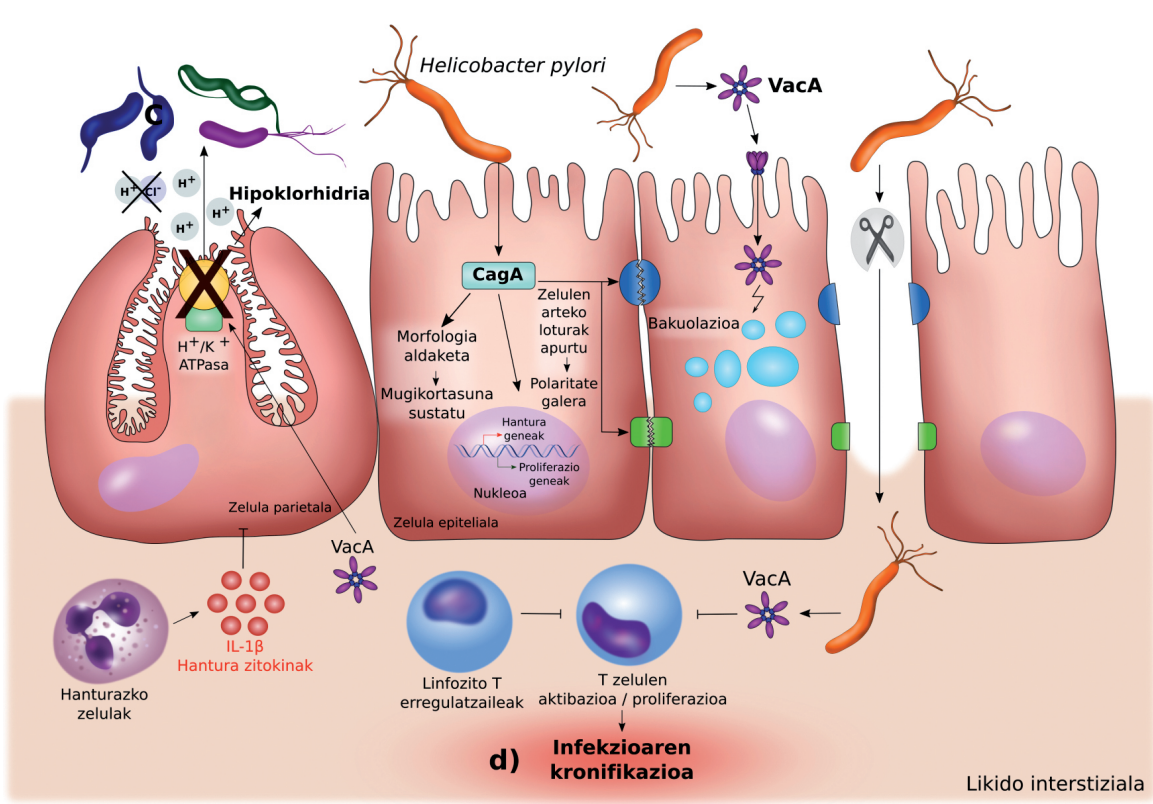

3. irudia. Urdaileko minbiziaren garapena sustatzen duten mekanismoen deskribapena. a) Hantura-zitokinek eta $H$. pyloriren proteina zitotoxikoek hipoklorhidria eragiten dute. Horrek urdailean bakterioak hazteko ingurune egokia sortzen du, hantura mantenduz eta estres oxidatzailea sustatuz. b) Bakterioaren CagA zitotoxinak urdaileko zelulen barnean eragin onkogenikoa dauka, zelulen polaritatea galduz, mugikortasuna eta proliferazioa sustatuz, eta hanturarekin erlazionaturiko geneen adierazpena handituz. c) VacA zitotoxinak urdaileko epitelioa kaltetzen du, bakuolak eratuz, besteak beste. d) T zelulen erantzunaren inhibizioak infekzioaren kronifikazioa eragiten du, $\mathrm{T}$ linfozito erregulatzaileak erreklutatuz eta VacA zitotoxinaren eraginez.

Minbiziaren garapena sustatzen duten $H$. pyloriren birulentzia faktore nagusiak Cag uharte patogeniko izeneko DNA segmentuan kodetuta daude [38]. Birulentzia handiko anduietan uharte patogenikoan kodetutako birulentzia faktoreen artean CagA zitotoxina eta IV. motako sekrezio sistemak daude [36]. Sekrezio sistema honen bidez, bakterioaren hainbat proteina, CagA zitotoxina besteak beste, ostalariaren urdaileko zeluletan sar 
A. Arbizu, A. Antoran, I. Buldain, A. Pellon, X. Guruceaga, L. Martin-Souto, L. Aparicio, A. Rementeria, F.L. Hernando, A. Ramirez-Garcia

daitezke [31]. Behin zelulen barnean, CagA zitotoxinak eragin onkogenikoa dauka, zelulen proliferazioa eta mugikortasuna sustatuz, polaritatea galduz, zelulen arteko loturak apurtuz eta hanturarekin erlazionaturiko geneen adierazpena handituz [31, 38].

$H$. pyloriren beste birulentzia faktore garrantzitsu bat bakterioaren andui gehienetan aurkitzen den VacA proteina zitotoxikoa da [37]. Zitotoxina honek ostalariaren urdaileko epitelioa kaltetzen du zelulen mintzean kanalak eta bakuolak eratuz eta zelula barneko iragazkortasuna eta apoptosia sustatuz. Gainera, proteina honek eragin immunoezabatzailea dauka, T zelulen erantzuna ekidinez eta, honela infekzioaren kronifikazioa erraztuz [31, 37, 38].

Bestalde, ostalariak $H$. pyloriren aurka sortutako erantzun immuneak ere minbiziaren garapena susta dezake [39]. Berezko erantzun immunean ekoizturiko produktu batzuk (zitokinak...) hantura eta estres oxidatzailea handituz minbizia sorrarazten duen mekanismorik garrantzitsuenetarikoak dira $[14,40]$. Konkretuki, oxigeno eta nitrogenoaren molekula erreaktiboek DNAn kalteak eta mutazioak areagotu, eta kalteak konpontzen dituzten entzimak inhibi ditzakete [38]. Gainera, hantura-zitokinek (IL-1 $\beta$, TNF- $\alpha . .$. eta $H$. pyloriren proteina zitotoxikoek, beste faktore batzuen artean, hipoklorhidria eragiten dute urdailean bestelako bakterioak hazteko ingurune egokia sortuz. Horrekin, hantura mantendu, estres oxidatzailea sustatu eta minbizia pairatzeko arriskua handitzen da [31].

Ostalariak bakterioaren aurka erantzun indartsu hau garatu arren, bakterioa kasu askotan urdailean gizakiaren bizitza osoan zehar mantentzen da, infekzioa kronifikatuz eta, ondorioz, minbizia pairatzeko probabilitatea handituz [31]. Hori $H$. pylorik berezko erantzun immunetik zein espezifikotik ihes egiteko dauzkan mekanismoekin erlazionatuta egon daiteke [14]. Zehazki, H. pylorik fagozitoen molekula erreaktiboen ekintza inhibitzeko entzimak, katalasak eta arginasak, ekoizten ditu. Gainera, makrofagoen apoptosia eragiten duten entzimak positiboki erregulatzen ditu [31]. Horrez gain, $H$. pyloriren infekzioetan $\mathrm{T}$ zelulen erantzuna negatiboki erregulatuta dago, T linfozito erregulatzaileak erreklutatuz urdaileko mukosetara [9] eta $\mathrm{T}$ zelulen aktibazioa inhibituz VacA zitotoxinaren bidez [41-43]. Azpimarratzekoa da mekanismo horiek bakterioaren ezabatzea ekiditeaz gain zelula neoplasikoen ezabatzea ere ekiditen dutela [14].

Hau guztia gutxi ez eta, $H$. pylorik gastrinaren sekrezioa sustatzen du, eta horrek hazkuntza-faktoreak, proteina antiapoptotikoak eta COX-2 entzimaren adierazpenak handitzen ditu. Hain zuzen ere, COX-2 entzimaren espresioa gastrinak ez ezik, hantura-zitokinek eta hazkuntza-faktoreek ere induzitzen dute $[31,38]$. COX-2 entzimari esker ekoiztutako molekulek, prostaglandinak batez ere, zelulen apoptosia inhibitzen eta haien transformazioa sustatzen dute, eta proliferazioa, atxikidura, angiogenesia eta inbaditzeko zelula gaiztoen ahalmena handitzen dute $[14,31,38]$. 
Mikroorganismoek minbizia eragin dezakete?

\section{ONDDOAK}

Onddo mikroskopikoek, birus eta bakterioekin gertatzen den bezala, minbiziaren sorrera edo garapena era zuzenean eta ez-zuzenean bultza dezakete. Kasu honetan, onddoek minbizian era zuzenean daukaten eraginari buruzko artikulu batzuk besterik ez daude argitaratuta. Hala ere, onddo batzuek ekoizten dituzten mikotoxinen eraginaren bitartez ere susta dezakete minbiziaren garapena. Hurrengo puntuetan mekanismo zuzenak eta ez-zuzenak azalduko dira.

Minbizian eragin ez-zuzena duen onddoen faktore garrantzitsuena mikotoxinak dira. Mikotoxinak onddoek sortutako ekoizkinak dira, animalientzako eragin toxikoa izan dezaketenak. Onddo ugariek toxinak ekoiztu ahal izan arren, genero garrantzitsuenak Aspergillus, Fusarium eta Penicillium dira. Molekula hauek gizakiok kontsumitutako produktu ezberdinetan aurkitu daitezke, batez ere landareetatik eratorritako produktuetan, artoan besteak beste (1. Taula). Mikotoxina gehienek gizakiongan minbizia eragin ote dezaketen argi ez dagoenez, artikulu honetan soilik lau mikotoxina esanguratsuenak azalduko dira: B1 aflatoxina, esterigmatozistina, B1 fumonisina eta A okratoxina.

1. taula. Kartzinogenikoak izan daitezkeen mikotoxina garrantzitsuenak.

\begin{tabular}{|c|c|c|c|c|}
\hline Mikotoxina & Onddoa & Sailkapena* & Elikagaiak & Minbizia \\
\hline Aflatoxinak & $\begin{array}{l}\text { A.flavus } \\
\text { A.parasiticus }\end{array}$ & 1/2B taldea & $\begin{array}{l}\text { Artoa, kakahueteak, } \\
\text { zerealak, espeziak, in- } \\
\text { txaurrak, esnea, hara- } \\
\text { gia, fruitu lehorrak }\end{array}$ & $\begin{array}{l}\text { Gibela, } \\
\text { behazun-xixkua }\end{array}$ \\
\hline Esterigmatozistina & A. versicolor & 2B taldea & $\begin{array}{l}\text { Garia, zerealak, soja, } \\
\text { ogia, gazta, espeziak, } \\
\text { kafe aleak, pistatxoak }\end{array}$ & \\
\hline Fumonisinak & $\begin{array}{l}F . \text { verticilloides } \\
F . \text { proliferatum }\end{array}$ & 2B taldea & Garia, artoa, arroza & $\begin{array}{l}\text { Gibela, } \\
\text { hestegorria }\end{array}$ \\
\hline Okratoxinak & $\begin{array}{l}\text { Aspergillus spp. } \\
\text { Penicillium spp. }\end{array}$ & 2B taldea & $\begin{array}{l}\text { Garia, artoa, ardoa, } \\
\text { kafea, kakaoa, espe- } \\
\text { ziak, haragia, esnea }\end{array}$ & $\begin{array}{l}\text { Urdaila, gibela, } \\
\text { gernu-hodia }\end{array}$ \\
\hline
\end{tabular}

* Minbiziaren Ikerketarako Nazioarteko Agentziaren (IARC) sailkapena: 1 taldea: gizakiontzako kartzinogenoa; 2A: gizakiontzako kartzinogeno probablea; 2B: gizakiontzako kartzinogeno posiblea; 3: gizakiontzako kartzinogenoa dela ezin da ziurtatu, baina animalientzat izan daiteke; 4: ez da kartzinogenoa gizakiontzako.

Mikotoxina guztien artean aflatoxinak dira gizakiontzako 1. taldeko kartzinogenoen artean sailkatu diren bakarrak. Haien artean, B1 aflatoxina 
A. Arbizu, A. Antoran, I. Buldain, A. Pellon, X. Guruceaga, L. Martin-Souto, L. Aparicio, A. Rementeria, F.L. Hernando, A. Ramirez-Garcia

da eragin toxiko handiena duena. eta batez ere gibeleko minbiziarekin eta behazun-xixkuko minbiziarekin dago erlazionatuta. Urtero mundu osoan gertatzen diren gibel minbizien $\% 5$ eta $\% 28$ artean aflatoxinaren eraginaren ondorio dira [44], eta biztanlerian detektatutako aflatoxina maila jaisten den heinean gibel minbiziaren eragina murrizten da [45]. Gainera, B hepatitis birusarekin kutsatutako pertsonek gibeleko minbizia pairatzeko arrisku handiagoa daukate aflatoxina hartzen badute [44]. Kartzinogenesi-mekanismoei dagokienez, aflatoxinek sustantzia mutagenoen sorrera, kromosomen apurketa eta aberrazioak, eta DNAn aldaketak eragiten dituzte, adibidez, p53 tumore-ezabatzailearen genean mutazioak sortuz, edo planifikatu gabeko DNAren sintesia bultzatuz [44, 46]. Aflatoxinekin erlazionatuta, esterigmatozistina da aipatzeko modukoa, B1 aflatoxinaren aitzindaria delako. Mikotoxina honek biriketan eta gibelean tumoreak eragiteko gaitasuna du, DNAn kalteak sortuz [47].

Fumonisinak ere minbiziarekin erlazionatutako mikotoxina garrantzitsuak dira. Talde honetan, 15 mikotoxina baino gehiago ezagutzen dira, eta horietatik, kartzinogeno eta tumore-sortzaile indartsuena B1a da, hestegorriko eta gibeleko minbiziarekin erlazionatu dena [44, 48-51]. B1 fumonisinaren minbizia sortzeko mekanismoen artean zelulen apoptosiaren inhibizioa edota P450 zitokromoaren espresioaren handitzea daude $[52,53]$. Lehenengo mekanismoak mutazioak dituzten zelulen ugaltzea eta bigarrenak molekula prokartzinogeno eta promutageno ezberdinen aktibazioa faboratzen dute.

A okratoxinari dagokionez, urdaileko minbiziarekin, gibeleko minbiziarekin eta gernu-hodiko tumoreekin erlazionatu da [54-56]. Mikotoxina honek hiru kartzinogenesi mekanismo nagusi ditu: zelula gastrikoak minbizia sortzeko gai diren zelulak bihurtzen ditu [54], kontrol gabeko zelulen hazkuntza bultza dezake [57] eta DNAn apurketak eragiten ditu [58].

Beste toxina batzuek ere minbizia sortzeko gaitasuna izan dezakete: adibidez Fusarium generoko espezie batzuk ekoiztutako zearalenonak, deoxinibalenolak, nibalenolak, X fusarenonak eta T-2 toxinak, Gyromitra esculentak ekoiztutako giromitrinak edota Penicillium islandicumek ekoiztutako luteoskirinak eta rugulosinak. Hala ere, IARCek 3. taldean sailkatu ditu, hau da, gizakiongan kantzerigenoak direla ziurtatzeko frogak ez dira nahikoak.

Mikotoxinak alde batera utzita, onddoen presentzia zuzena ere minbiziarekin erlazionatu da, batez ere Candida albicans legamiaren kasuan. Izan ere, minbizia pairatzen duten pertsonek jasotako kimioterapiaren ondorioz kandidiasia pairatu dezaketela ezaguna zen haien immunitate-sistema ahulduta zegoelako [59]. Hala ere, azken urteotan $C$. albicansek minbizia sortzeko, bultzatzeko eta metastasiak sustatzeko gaitasuna ere izan dezakeela ondorioztatu da [60-62].

Batez ere, Candida aho eta hestegorriko minbiziarekin erlazionatu da $[63,64]$. Izan ere, askotan ahoko minbiziaren lesioak Candida dagoen 
Mikroorganismoek minbizia eragin dezakete?

tokietan agertzen dira [65] eta Candidaren presentzia handiagoa da aho minbizi lesioetan inguruko ehun osasuntsuetan baino [66].

Candidak minbizia bultzatu dezake mekanismo ezberdinen bidez (4. Irudia). Alde batetik, onddo honek endotelio-zeluletan kartzinogenesian parte hartzen duten geneen gainadierazpena sustatzen du [67]. Bestalde, Candidarekiko kontaktuaren ondorioz M1 motako makrofagoak M2 profilera aldatzen dira; azken hauek minbizi-zelulen ugaritzea eta migrazioa sustatzen dute [68].

a)

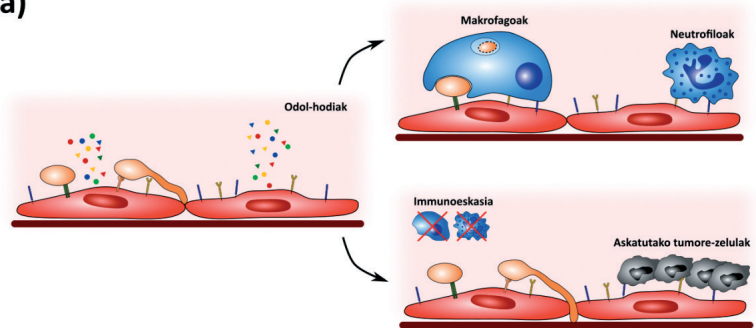

c)

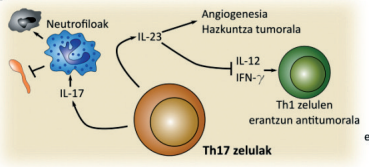

d)

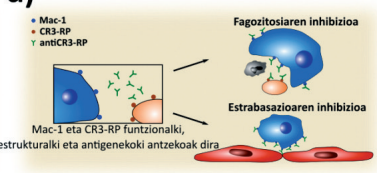

b)

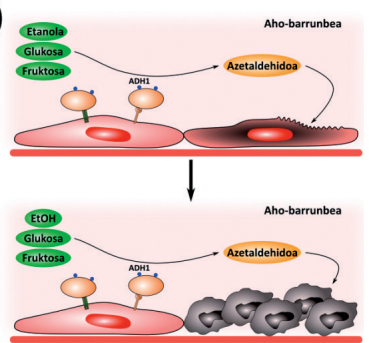

e)

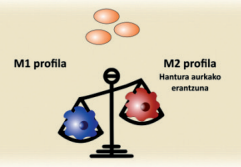

4. irudia. Candida albicans onddoak minbiziaren sorrera eta hedapena sustatu dezake mekanismo ezberdinen bitartez. a) C. albicans onddoa ezagutzean, odol-hodietako endotelio-zelulek zitokinak eta kimiokinak askatu eta adhesio-molekulak adierazten dituzte immunitate-sistemaren zelulak erakartzeko. Immunoeskasia pairatzen duten pertsonen kasuan, minbizia daukaten pazienteengan adibidez, zelula immuneak kontzentrazio txikian daude odolean eta adhesio-molekulak libre geratzen dira. Kasu horretan, tumore primariotik askatutako tumore-zelulak adhesio-molekula horien bidez endotelio-zeluletara lotu daitezke, metastasia eraginez. b) C. albicans-ek Adh1 entzimaren bitartez etanola eta azukreak degradatzen ditu, eta kantzerigenoa den azetaldehidoa sortzen da. c) Th17 linfozitoen erantzuna Candidaren aurkako erantzun immunean garrantzitsua da, baina minbiziaren sustapenarekin ere erlazionatu da angiogenesia faboratuz eta Th1 erantzuna inhibituz. d) C. albicans onddoaren CR3-RP proteina eta makrofagoen Mac-1 proteina oso antzekoak dira. Beraz, immunitate-sistemak CR3-RP-ren aurka sortutako antigorputzek, Mac-1 proteina ere ezagutu dezakete, fagozitosia eta makrofagoen estrabasazioa eragotziz eta haien funtzioa oztopatuz. f) $C$. albicans-en presentziaren ondorioz M1 profileko makrofagoak M2 bilakatzen dira, hantura aurkako erantzuna bultzatuz, eta Th1 erantzuna oztopatuz.

Horietaz gain, orain dela gutxi, Ramirez-Garciak eta kolaboratzaileek [69] Candidaren beste lau mekanismo kantzerigeno desberdin des- 
A. Arbizu, A. Antoran, I. Buldain, A. Pellon, X. Guruceaga, L. Martin-Souto, L. Aparicio, A. Rementeria, F.L. Hernando, A. Ramirez-Garcia

kribatu dituzte errebisio batean. Horietatik, lehenengoa konposatu kartzinogenoak sortzeko gaitasuna da, nitrosaminak edo azetaldehidoa, esate baterako. Izan ere, ahoko minbizia sor dezaketen lesioetatik isolatutako $C$. albicans anduiek azetaldehidoa sortzeko gaitasun handiagoa daukate bestelako anduiek baino [70]. Bigarren mekanismoa infekzioari lotutako hantura da, zeinak, artikulu honetan azaldu denez, tumoreen sorrera eta hedapena, metastasia faboratuz, susta dezakeen. Beste mekanismo bat tumore zelulen ugaltzea bultza dezakeen Th17 linfozitoen erantzun immunearen sustapena da. Azken mekanismoa mimetismo molekularra da. Honetan, ostalariaren molekulen antzekoak diren mikroorganismoaren molekulen aurkako erantzunaren ondorioz, ostalariaren zelulen kontra ere erantzuten da, adibidez minbizia kontrolatzen duten immunitate sistemaren zelulen aurka. Mekanismo hauek soilik $C$. albicansen kasuan aztertu diren arren, beste onddo batzuek prozesu antzekoen bitartez minbizia susta dezaketela kontuan izan behar da.

\section{ONDORIOA}

Gaur egun, zientzialariek ez daukate zalantzarik mikroorganismoek eragina izan dezaketela minbizia sortzeko eta garatzeko prozesuan. Izan ere, artikulu honetan aipatu den bezala, gure gorputzarekin erlazionatutako mikroorganismo talde desberdin ohikoenek minbizia eragiteko mekanismo ugari dauzkate, bai zuzenak bai ez-zuzenak. Mikroorganismo batzuek minbiziarekin daukaten erlazioa oso ezaguna izan arren, hala nola $H$. pylori bakterioa nahiz giza papilomabirusa, beste mikroorganismo asko ere erlazionatuta daude tumoregenesiarekin. Horien artean, bakterioak eta birusak ez ezik badira onddoak ere, $C$. albicans esaterako.

Mikroorganismoen efektu protumoralak asko eta oso desberdinak dira. Espezie bakoitzak bere mekanismo espezifikoak ditu eta gehienak oraindik ezezagunak dira. Hala ere, beste batzuk mikroorganismo askotarako komunak dira eta, horien artean, azpimarratzekoa da hantura gehiegizkoa nahiz iraunkorra.

Orain arte, minbiziarekin erlazionatutako heriotza-tasa altua dela eta, zientzialariek batez ere haren diagnostikoan eta tratamenduan fokatu dituzte beren ahaleginak eta, ondorioz, ezin izan dute sakonean mikroorganismoek minbiziaren sorreran izan dezaketen zeregina ikertu. Gaur egun, mikroorganismo batzuk minbiziarekin erlazionatuta daudela argi dago, baina minbiziaren sorreran eragina izan dezaketen faktoreak ikertzen diren heinean, espezie eta mekanismo desberdin gehiago erlazionatuko dira tumore-prozesuarekin. Hori dela eta, zenbat eta aurrerapauso gehiago eman faktore tumoregenikoen eta metastasikoen ezagutzan, orduan eta aukera gehiago izango ditugu gaixotasun suntsitzaile hau kontrolatu eta sendatu ahal izateko. 
Mikroorganismoek minbizia eragin dezakete?

\section{BIBLIOGRAFIA}

[1] PARKIN D.M. 2006. « The global health burden of infection-associated cancers in the year 2002». International Journal of Cancer, 118, 3030-3044.

[2] DZUTSEV A., BADGER J.H., PEREZ-CHANONA E., ROY S., SALCEDO R., SMITH C.K., et al. 2017. «Microbes and Cancer». Annual Reviews in Immunology, 35, 199-228.

[3] SARID R. eta GAO S-J. 2011. «Viruses and human cancer: From detection to causality». Cancer Letters, 305, 218-227.

[4] MESRI E.A., FEITELSON M.A. eta MUNGER K. 2014. «Human viral oncogenesis: A cancer hallmarks analysis». Cell Host Microbe, 15, 266-282.

[5] ZHANG X., ZHANG Z., ZHENG B., HE Z., WINBERG G. eta ERNBERG I. 2013 «An update on viral association of human cancers». Archives Virology, 158, 1433-1443.

[6] NA B., HUANG Z., WANG Q., QI Z., TIAN Y., LU CC, et al. 2011. «Transgenic expression of entire Hepatitis B virus in mice induces hepatocarcinogenesis independent of chronic liver injury». PLoS One, 6: e26240.

[7] BAUMFORTH K.R.N., BIRGERSDOTTER A., REYNOLDS G.M., WEI W., KAPATAI G., FLAVELL J.R., et al. 2008. «Expression of the EpsteinBarr virus-encoded Epstein-Barr Virus nuclear antigen 1 in Hodgkin's lymphoma cells mediates up-regulation of CCL20 and the migration of regulatory T cells». American Journal of Pathology, 173, 195-204.

[8] CHETAILlE B., BERTUCCI F., FINETTI P., ESTERNI B., STAMATOULLAS A., PICQUENOT M., et al. 2009. «Molecular profiling of classical Hodgkin lymphoma tissues uncovers variations in the tumor microenvironment and correlations with EBV infection and outcome». Blood, 113, 2765-2776.

[9] KANDULSKI A., WEX T., KUESTER D., PEITZ U., GEBERT I., ROESSNER A., et al. 2008. «Naturally occurring regulatory T cells $\left(\mathrm{CD} 4^{+}, \mathrm{CD} 25\right.$ $\left.\mathrm{HIGH}, \mathrm{FOXP}^{+}\right)$in the antrum and cardia are associated with higher $H . p y-$ lori colonization and increased gene expression of TGF- $\beta 1 »$. Helicobacter, 13, 295-303.

[10] KUNDU J.K. eta SURH Y.J. 2012. «Emerging avenues linking inflammation and cancer» Free Radical Biology and Medicine, 52, 2013-2037.

[11] CHANG M.H. eta JEANG K.T (eds.). 2014. Viruses and Human cancer. Ativiral Treatment and Cancer Control. Springer-Verlag Berlin Heidelberg. 2014.

[12] DELBUE S., COMAR M. eta FERRANTE P. 2017. «Review on the role of the human Polyomavirus JC in the development of tumors». Infectious agents and cancer, 12, 1-14.

[13] LIAO J.B. 2006. «Viruses and human cancer». Yale Journal of Biology and Medicine, 79, 115-122. 
A. Arbizu, A. Antoran, I. Buldain, A. Pellon, X. Guruceaga, L. Martin-Souto, L. Aparicio, A. Rementeria, F.L. Hernando, A. Ramirez-Garcia

[14] PORTA C., RIBOLDI E. eta SICA A. 2011. «Mechanisms linking pathogens-associated inflammation and cancer». Cancer Letters, 305, 250-62.

[15] READ S.A. eta DOUGLAS M.W. 2014. «Virus induced inflammation and cancer development». Cancer Letters, 345, 174-181.

[16] TAKEDA H., TAKAI A., INUZUKA T. eta MARUSAWA H. 2016. «Genetic basis of hepatitis virus-associated hepatocellular carcinoma: linkage between infection, inflammation, and tumorigenesis». Journal of Gastroenterology, 52, 1-13.

[17] TSAI M., LIN X., SHUMILOV A., BERNHARDT K., FEEDERLE R., POIREY R., et al. 2016. «The biological properties of different Epstein-Barr virus strains explain their association with various types of cancers». Oncotarget, $8,10238-10254$.

[18] THOMPSON M.P. eta KURZROCK R. 2004 . «Epstein-Barr virus and cancer». Clinical Cancer Research. 10, 803-821.

[19] PATTLE S.B. eta FARRELL P.J. 2006. «The role of Epstein - Barr virus in cancer». Expert Opinion on Biological Therapy, 6, 1193-1205.

[20] MAGER D. 2006. «Bacteria and cancer: cause, coincidence or cure? A review». Journal of Translational Medicine, 4, 14.

[21] NOUGAYRÈDE J.P., TAIEB F., DE RYCKE J. eta OSWALD E. 2005. «Cyclomodulins: Bacterial effectors that modulate the eukaryotic cell cycle». Trends in Microbiology, 13, 103-110.

[22] KOCAZEYBEK B. 2003. «Chronic Chlamydophila pneumoniae infection in lung cancer, a risk factor: A case-control study». Journal of Medical Microbiology. 52, 721-726.

[23] LITTMAN A.J., WHITE E., JACKSON L.A., THORNQUIST M.D., GAYDOS C.A., GOODMAN G.E., et al. 2004. «Chlamydia pneumoniae infection and risk of lung cancer». Cancer Epidemiology, Biomarkers \& Prevention. 13, 1624-1630.

[24] COLLINS D., HOGAN A.M. eta WINTER D.C. 2011. «Microbial and viral pathogens in colorectal cancer». Lancet Oncology, 12, 504-512.

[25] KOSTIC A.D., CHUN E., ROBERTSON L., GLICKMAN J.N., GALLINI C.A., MICHAUD M., et al. 2013. «Fusobacterium nucleatum potentiates intestinal tumorigenesis and modulates the tumor-immune microenvironment». Cell Host \& Microbe. 14, 207-215.

[26] MCCOY A.N., ARAÚJO-PÉREZ F., AZCÁRATE-PERIL A., YEH J.J., SANDLER R.S. eta KEKU T.O. 2013. «Fusobacterium is associated with colorectal adenomas». PLoS One. 8:e53653.

[27] MARTIN HM, CAMPBELL BJ, HART CA, MPOFU C, NAYAR M, SINGH R, et al. 2004. «Enhanced Escherichia coli adherence and invasion in Crohn's disease and colon cancer». Gastroenterology. 127, 80-93.

[28] SIEGERT C. eta OVERBOSCH D. 1995. «Carcinoma of the colon presenting as Streptococcus sanguis bacteremia». The American Journal of Gastroenterology. 90, 1528-1529. 
Mikroorganismoek minbizia eragin dezakete?

[29] KIM N.H., PARK J.P., JEON S.H., LEE Y.J., CHOI H.J., JEONG K.M., et al. 2002. «Purulent pericarditis caused by group $\mathrm{G}$ streptococcus as an initial presentation of colon cancer». Journal of Korean Medical Science. 17, 571-573.

[30] ELLMERICH S., SCHOLLER M., DURANTON B., GOSSE F., GALLUSER M., KLEIN J-P., et al. 2000. «Promotion of intestinal carcinogenesis by Streptococcus bovis». Carcinogenesis. 21, 753-756.

[31] WROBLEWSKI L.E., PEEK R.M. eta WILSON K.T. 2010. «Helicobacter pylori and gastric cancer: Factors that modulate disease risk». Clinical Microbiology Reviews. 23, 713-739.

[32] YEH J.M., GOLDIE S.J., KUNTZ K.M. eta EZZATI M. 2009. «Effects of Helicobacter pylori infection and smoking on gastric cancer incidence in China: A population-level analysis of trends and projections». Cancer Causes \& Control. 20, 2021-2029.

[33] SUZUKI H., IWASAKI E. eta HIBI T. 2009. «Helicobacter pylori and gastric cancer». Gastric Cancer. 12, 79-87.

[34] UEMURA N., OKAMOTO S., YAMAMOTO S., MATSUMURA N., YAMAGUCHI S., YAMAKIDO M., et al. 2001. «Helicobacter pylori infection and the development of gastric cancer». The New England Journal of Medicine. 345, 784-789.

[35] PLUMMER M., FRANCESCHI S., VIGNAT J., FORMAN D. eta DE MARTEL C. 2015. «Global burden of gastric cancer attributable to Helicobacter pylori». International Journal of Cancer. 136, 487-490.

[36] ISHAQ S. eta NUNN L. 2015. «Helicobacter pylori and gastric cancer: A state of the art review». Gastroenterology and Hepatology from Bed to Bench, 8, S6-S14.

[37] NAUMANN M., SOKOLOVA O., TEGTMEYER N. eta BACKERT S. 2017. «Helicobacter pylori: A paradigm pathogen for subverting host cell signal transmission». Trends in Microbiology. 25, 316-328.

[38] KONTUREK P.C., KONTUREK S.J. eta BRZOZOWSKI T. 2009. «Helicobacter pylori infection in gastric cancerogenesis». Journal of Physiology and Pharmacology. 60, 3-21.

[39] ROBINSON K., ARGENT R.H. eta ATHERTON J.C. 2007. «The inflammatory and immune response to Helicobacter pylori infection». Best Practice and Research: Clinical Gastroenterology. 21, 237-259.

[40] ERNST P.B. eta GOLD B.D. 2000. «The disease spectrum of Helicobacter pylori : The immunopathogenesis of gastroduodenal ulcer and gastric cancer». Annual Review of Microbiology. 54, 615-640.

[41] BONCRISTIANO M., PACCANI S.R., BARONE S., ULIVIERI C., PATRUSSI L., ILVER D., et al. 2003. «The Helicobacter pylori vacuolating toxin inhibits $\mathrm{T}$ cell activation by two independent mechanisms». The Journal of Experimental Medicine. 198, 1887-1897.

[42] GEBERT B., FISCHER W., WEISS E., HOFFMANN R. eta HAAS R. 2003. «Helicobacter pylori vacuolating cytotoxin inhibits T lymphocyte activation». Science. 301, 1099-1102. 
A. Arbizu, A. Antoran, I. Buldain, A. Pellon, X. Guruceaga, L. Martin-Souto, L. Aparicio, A. Rementeria, F.L. Hernando, A. Ramirez-Garcia

[43] SUNDRUD M.S., TORRES V.J., UNUTMAZ D. eta COVER T.L. 2004. «Inhibition of primary human $\mathrm{T}$ cell proliferation by Helicobacter pylori vacuolating toxin (VacA) is independent of VacA effects on IL-2 secretion». Proceedings of the National Academy of Sciences of the Unitated States of America. 101, 7727-7732.

[44] DE RUYCK K., DE BOEVRE M., HUYBRECHTS I. eta DE SAEGER S. 2015. «Dietary mycotoxins, co-exposure, and carcinogenesis in humans: Short review». Mutation Research - Reviews in Mutation Research. 766, 32-41.

[45] CHEN J.G., EGNER P.A., NG D., JACOBSON L.P., MUÑOZ A., ZHU Y.R. et al. 2013. «Reduced aflatoxin exposure presages decline in liver cancer mortality in an endemic region of China». Cancer Prevention Research. 6, 1038-1045.

[46] MAGNUSSEN A. eta PARSI M.A. 2013. «Aflatoxins, hepatocellular carcinoma and public health». World Journal of Gastroenterology. 19, 1508-12.

[47] GAO W., JIANG L., GE L., CHEN M., GENG C., YANG G., et al. 2015. «Sterigmatocystin-induced oxidative DNA damage in human liver-derived cell line through lysosomal damage». Toxicology In Vitro. 29, 1-7.

[48] XUE K.S., TANG L., CAI Q., SHEN Y., SU J. eta WANG J-S. 2015. «Mitigation of fumonisin biomarkers by green tea polyphenols in a high-risk population of hepatocellular carcinoma». Scientific Reports. 5, 17545.

[49] SHEPHARD G.S., MARASAS W.F.O., BURGER H-M., SOMDYALA N.I.M., RHEEDER J.P., VAN DER WESTHUIZEN L., et al. 2007. «Exposure assessment for fumonisins in the former Transkei region of South Africa». Food Additives \& Contaminants. 24, 621-629.

[50] SUN G., WANG S., HU X., SU J., HUANG T., YU J., et al. 2007. «Fumonisin B1 contamination of home-grown corn in high-risk areas for esophageal and liver cancer in China». Food Additives \& Contaminants. 24, 181-185.

[51] SUN G., WANG S., HU X., SU J., ZHANG Y., XIE Y., et al. 2011. «Cocontamination of aflatoxin B1 and fumonisin B1 in food and human dietary exposure in three areas of China». Food Additives \& Contaminants, Part A. 28, 461-470.

[52] CHUTURGOON A.A., PHULUKDAREE A. eta MOODLEY D. 2015. «Fumonisin B1 inhibits apoptosis in HepG2 cells by inducing Birc-8/ILP-2». Toxicology Letters. 235, 67-74.

[53] CHUTURGOON A.A., PHULUKDAREE A. eta MOODLEY D. 2014. «Fumonisin B1 modulates expression of human cytochrome P450 1b1 in human hepatoma (Hepg2) cells by repressing Mir-27b». Toxicology Letters. 227, 50-55.

[54] JIA X., CUI J., MENG X., XING L., SHEN H., WANG J., et al. 2016. «Malignant transformation of human gastric epithelium cells via reactive oxygen species production and $\mathrm{Wnt} / \beta$-catenin pathway activation following 40 -week exposure to ochratoxin A». Cancer Letters, 372, 36-47. 
Mikroorganismoek minbizia eragin dezakete?

[55] IBRAHIM A.S., ZAGHLOUL H. eta BADRIA F.A. 2013. "Case Report Evidence of Relationships between Hepatocellular Carcinoma and Ochratoxicosis». PLoS One, 8, 1-7.

[56] PFOHL-LESZKOWICZ A., TOZLOVANU M., MANDERVILLE R., PERAICA M., CASTEGNARO M. eta STEFANOVIC V. 2007. «New molecular and field evidences for the implication of mycotoxins but not aristolochic acid in human nephropathy and urinary tract tumor». Molecular Nutrition and Food Research, 51, 1131-1146.

[57] QI X., YU T., ZHU L., GAO J., HE X., HUANG K., et al. 2014. «Ochratoxin A induces rat renal carcinogenicity with limited induction of oxidative stress responses». Toxicology and Applied Pharmacology, 280, 543-549.

[58] KURODA K., HIBI D., ISHII Y., YOKOO Y., TAKASU S., KIJIMA A. et al. 2015. «Role of p53 in the progression from ochratoxin A-Induced DNA damage to gene mutations in the kidneys of mice». Toxicological Sciences, 144, 65-76.

[59] LALLA R.V., LATORTUE M.C., HONG C.H., ARIYAWARDANA A., D'AMATO-PALUMBO S., FISCHER D.J., et al. 2010. «A systematic review of oral fungal infections in patients receiving cancer therapy». Supportive Care in Cancer, 18, 985-992.

[60] DWIVEDI P.P., MALLYA S. eta DONGARI-BAGTZOGLOU A. 2009. «A novel immunocompetent murine model for Candida albicans-promoted oral epithelial dysplasia». Medical Mycology, 47, 157-167.

[61] SANO T., OZAKI K., TERAYAMA Y., KODAMA Y. eta MATSUURA T. 2014. «A novel diabetic murine model of Candida albicans -induced mucosal inflammation and proliferation». Journal of Diabetes Research, 2014, 509325.

[62] RODRÍGUEZ-CUESTA J., HERNANDO F.L., MENDOZA L., GALLOT N., DE CERIO A.A., MARTÍNEZ-DE-TEJADA G., et al. 2010. «Candida albicans enhances experimental hepatic melanoma metastasis». Clinical and Experimental Metastasis, 27, 35-42.

[63] GHOLIZADEH P., ESLAMI H., YOUSEFI M., ASGHARZADEH M., AGHAZADEH M. eta KAFIL H.S. 2016. «Role of oral microbiome on oral cancers, a review». Biomedicine and Pharmacotherapy, 84, 552-558.

[64] SANJAYA P.R., GOKUL S., GURURAJ PATIL B. eta RAJU R. 2011. «Candida in oral pre-cancer and oral cancer». Medical Hypotheses, 77, 1125-1128.

[65] RAUTEMAA R., HIETANEN J., NIISSALO S., PIRINEN S. eta PERHEENTUPA J. 2007. «Oral and oesophageal squamous cell carcinoma - A complication or component of autoimmune polyendocrinopathy-candidiasisectodermal dystrophy (APECED, APS-I) ». Oral Oncology, 43, 607-613.

[66] ALNUAIMI A.D., WIESENFELD D., O'BRIEN-SIMPSON N.M., REYNOLDS E.C. eta MCCULLOUGH M.J. 2015. «Oral Candida colonization in oral cancer patients and its relationship with traditional risk factors of oral cancer: A matched case-control study». Oral Oncology, 51, 139-145. 
A. Arbizu, A. Antoran, I. Buldain, A. Pellon, X. Guruceaga, L. Martin-Souto, L. Aparicio, A. Rementeria, F.L. Hernando, A. Ramirez-Garcia

[67] LIM C.S.Y., ROSLI R., SEOW H.F. eta CHONG P.P. 2011. «Transcriptome profiling of endothelial cells during infections with high and low densities of C. albicans cells». International Journal of Medical Microbiology, 301, 536546.

[68] REALES-CALDERÓN J.A., AGUILERA-MONTILLA N., CORBÍ Á.L., MOLERO G. eta GIL C. 2014. «Proteomic characterization of human proinflammatory M1 and anti-inflammatory M2 macrophages and their response to Candida albicans». Proteomics, 14, 1503-1518.

[69] RAMIREZ-GARCIA A., REMENTERIA A., AGUIRRE-URIZAR J.M., MORAGUES M.D., ANTORAN A., PELLON A. et al. 2016. «Candida albicans and cancer: Can this yeast induce cancer development or progression?». Critical Reviews in Microbiology, 42, 181-193.

[70] GAINZA-CIRAUQUI M.L., NIEMINEN M.T., NOVAK FRAZER L., AGUIRRE-URIZAR J.M., MORAGUES M.D. eta RAUTEMAA R. 2013. «Production of carcinogenic acetaldehyde by Candida albicans from patients with potentially malignant oral mucosal disorders». Journal of Oral Pathology and Medicine, 42, 243-249. 